\title{
Bank Service Quality, Mobile Connectivity and Adoption of Internet Banking Among Selected University Students in Oyo State Nigeria
}

\author{
Onaolapo A. R., Ph.D, Anene E. C. Ph.D \\ Department of Management and Accounting \\ Faculty of Management Science \\ Ladoke Akintola University of Technology, Ogbomoso, Nigeria \\ araonaolapo@lautech.edu.ng
}

\begin{abstract}
Quality of mobile connectivity in Nigeria has accounted for significant 'Digital divide' in term of usability between voice and data transmission with effect on quality of operation in some organization especially in the financial sector. This paper evaluates bank service quality, mobile connectivity and adoption of internet banking among selected University Students in Oyo state Nigeria.
\end{abstract}

Data are mainly primary with a structured questionnaire and focus group constituting the major instruments for data collection. Collected data are analyzed for relationship using both regression and correlation analysis.

Findings from the study revealed that Service Quality, trust and technophobia are significant attributes determining customers' adoption of internet for bank services with $p$ and t-values at (0.00) 12.5; 0.000 (5.89) and 0.097 (1.66) at 5\% and 10\% level of significance. Loyalty to bank branch (llb) and technical skill acquisition are predictive attributes for perceived credibility given an overall $R^{2}=0.9542$ with Technical skill acquisition (tsa) and technophobia constituting significant attributes for assessing bank website quality.

Furthermore; only service quality $(s q)$ and technophobia has significant influence on mobile service connectivity. On the supply side a regression analysis of relationship between selected bank specific variables such as deposit size, Net-profit, ICT investment and Capitalization indicate high predictive influence of these variables with shareholders equity given $R^{2}=0.9511$. Based on these findings the study concludes that bank service quality and availability of mobile service have significant influence on mobile connectivity and recommendations are made in line with the findings and conclusion.

\section{INTRODUCTION}

Internet or online banking relates to online system which allows bank customers to plug into a host of banking services from a personal computer or kindred electronic devices by connecting with a bank computer through an internet mobile connectivity. The growth of the internet and Information Technology (IT) has revolutionalized traditional banking services from the rudimentary savings and lending system to include an array of banking services ranging from checking accounts, credit card and money market transactions; among others. The provision of banking and related services through the application of extensive information technology otherwise referred to as virtual banking commenced in the seventies. According to Shelkar \& Shelkar (2013) virtual banking encompassed such services as the ATM, shared ATM Networks, Electronic fund Transfer at point of sale EFTPos, Smart card stored value cards, Phone banking and more recently internet banking. The salient features of this system of banking are the overwhelming reliance on information technology and less reliance on physical bank branches (i.e. branchless banking) to deliver banking services to the customer. According to Oginni et al (2013) internet technology has brought about a paradigm shift in banking operations to the extent that banks embrace the technology to enhance effective and extensive delivery of wide range of value added products and services.

Since the completion of the consolidation programme in December 2005, surviving Nigerian commercial banks have keyed in on electronic banking using the internet as a veritable medium to promote and deliver wide range of products. The quality of a bank website has also provided a niche for distinguishing one bank from its competitor; Ovia (2001) Ayo et al (2007) and Auta (2010). Apart from its impact on service delivery, there is also a tendency among Nigerian commercial banks to perceive the use of e-banking platform as a means for gaining acceptance in operation (customer 
brand loyalty) and a catalytic tool for enhancing performance. Vital benefits of internet banking apart from enabling banks to expand their reaches include opportunities for promoting products and services round the access to product, greater awareness and visibility to customer at no additional cost, lower cost of operating branch network given reduced staff overhead and enhanced efficiency. According to Mohammed and Saad (2011) the roles of banks as medium for enabling payment transaction and growth in commerce have been greatly enhanced recently by the development in communication system infrastructures thus making it possible to design myriads of financial products and services which are delivered through electronic banking. In particular Nigerian banks have reported an enlarged range of services that rapidly and accurately meet the needs of customers; Auta (2010).

The perceived opportunities and benefits that banks expect from internet notwithstanding, the medium is influenced by many challenges and limitations to the consumers as it involves some level of cost, awareness, knowledge and skill to operate as well as availability of mobile connectivity. Mobile connectivity according to Raji and Adeyemo (2008) refers to a form of electrical communication involving the processing, sending and receiving of information by electrical means. It is a medium for the exchange of information between two parties through fixed wire, fixed wireless and mobile services; Jochen (2000). Two major types of internet connectivity are found in sub-Saharan Africa (Nigeria inclusive), these are wired and wireless connection; IIC Africa (2013). The one applicable to the present study is the wireless or radio connection which entails any four of the following connections; namely Wireless Local Loop (WLL), Global System for Mobile Communication (GSM), Code Division Multiple Access (CDMA) and Worldwide Interoperability for microware Access (WiMax).

The last nine years have witnessed tremendous growth in internet adoption globally whether for banking or in other sectoral developmental purposes and noticeably 'big gap' exists in internet adoption between the developed and developing countries. This significant gap otherwise referred to as 'Digital divide' also extend to usability even within each developing nation as the ratio of mobile users (voice transmission, to internet users for data transmission) was low given about five times more of the former than for the latter. Such widening gap in usage can only be explained due to network connectivity as well as other factors; ranging from illiteracy, technophobia, poor access to power supply, high cost of usage, regulatory and infrastructural inadequacies. For instance EFina (2014) found that while 11.9million Nigerians (constituting 12.7\% Nigerian adults) have information of mobile money, (with $36.8 \%$ citing television source, about $87.3 \%$ are not aware and only a paltry $0.8 \%$ of those with its knowledge currently adopt mobile payment system. In addition majority of mobile money users employed the services for airtime purchase $(42.12 \%), 20.2 \%$ for sending money, $14.4 \%$ for receiving money, and $8.8 \%$ paying for goods and services, and $7.1 \%$ for paying bills.

Myriads of studies carried out on the relationship between e-banking adoption and bank performance indicate mixed evidences exist that linked positive financial performance to bank internet adoption. There are even some that reported negative impacts while there are others still that found no significant impact; Furst et al (2000), Hassan et al (2005) Egland et al (1998) and Al-Samad et al (2011). It is particularly noteworthy that relative dearth of empirical studies exist for the Nigerian case especially as regard the impact of e-banking on bank services and subsequent transformation of such into bottom-line performance. The present study is an attempt to examine the extent of relationship that exist between bank service quality, mobile connectivity and internet banking adoption by selected Nigerian University students in Oyo-state, Nigeria. Specifically, the study attempt an evaluation of relationship between bank services quality, availability of mobile connectivity and adoption of internet banking among university students in Oyo state, Nigeria as well as undertakes a supply side analysis of relationship between bank technology investment and financial performance.

\section{Four hypotheses formulated for the study are presented in the null form below:}

$\mathrm{Ho}_{1}$ No relationship exists between quality of bank website, brand loyalty, and adoptions of internet banking among Nigerian University Students in Oyo state Nigeria.

$\mathrm{Ho}_{2}$ No relationship exists between Quality of Mobile Connectivity and Student Loyalty to Nigerian Brand.

$\mathrm{Ho}_{3}$ Service Quality, Security, Trust, Loyalty and technophobia will not jointly nor independently predict adoption of internet banking. 
$\mathrm{Ho}_{4}$ No relationship exists between selected Nigerian Bank Technology Investment and Financial Performance.

\section{LITERATURE REVIEW}

Evolutionary phases of virtual banking according to Shekhar and Shekar (2013) can be classified into three namely; the inception phase wherein technology in its infancy was being introduced; the growth phase wherein the application and the technology is increasingly available to customers and maturity stage where the application is in widespread use and institutions not offering such application are likely to be disadvantaged. Nigeria banks websites development is already in the third phase of development and according to Chiemeke et al (2006) citing and expanding the work of Diniz (1998) are designed in line with the United States model with preference for four (4) major functionality. These are Information Delivery, Transaction Channel, Customer Relationship and Security Measure each of which can be evaluated based on three levels of interactivity; namely Basic, Intermediary and Advanced. The operational features of the third phase are encapsulated in the model in Fig. 2.1 below.

Table1. Features of the Maturity stage for Website Development

\begin{tabular}{|l|l|l|l|}
\hline & Basic & Intermediary & Advanced \\
\hline \multirow{3}{*}{ Information Delivery } & $\begin{array}{l}\text { New, contact Electronic } \\
\text { Brochure and Special } \\
\text { Events }\end{array}$ & $\begin{array}{l}\text { Search Engine } \\
\text { Recruitment Forms } \\
\text { Hot Links }\end{array}$ & $\begin{array}{l}\text { Advertisement } \\
\text { Discussion Group } \\
\text { Interface customization }\end{array}$ \\
\hline \multirow{3}{*}{ Transactional channel } & $\begin{array}{l}\text { Account Opening } \\
\text { ChequeBook and Card } \\
\text { Request }\end{array}$ & $\begin{array}{l}\text { Balance Enquiry } \\
\text { Fund Transfer } \\
\text { Bill Payment }\end{array}$ & $\begin{array}{l}\text { Electronic Cash } \\
\text { Electronic Cheque } \\
\text { Electronic Signature }\end{array}$ \\
\hline \multirow{3}{*}{ Security measures } & $\begin{array}{l}\text { e-mail } \\
\text { Suggestion Box } \\
\text { Complain forms }\end{array}$ & $\begin{array}{l}\text { Investment Advice } \\
\text { Software Download }\end{array}$ & $\begin{array}{l}\text { Video Conference } \\
\text { Chart } \\
\text { Services Development }\end{array}$ \\
\hline & $\begin{array}{l}\text { User Name } \\
\text { Password (change) }\end{array}$ & $\begin{array}{l}\text { Customer Code } \\
\text { Fire walls }\end{array}$ & $\begin{array}{l}\text { Digital Signature } \\
\text { Certificate } \\
\text { SSL128Bif Encryption }\end{array}$ \\
\hline
\end{tabular}

Source: An Adaptation from Chiemeke et al 2006.

Several attempts made to conceptualize the term internet banking have variously referred to it as either an employment of a remote delivery channel in performing banking services or an automated delivery of new and conventional banking products and services directly to customers through electronic interactive channels; Furst et al (2000); Kricks (2009) and Auta (2010). From the customers satisfaction perspective; it has been viewed as an automated process which has transformed traditional models of banking to ensure real time access, reduced operational cost for maximum efficiency in service delivery; Ovia (2001) Pyuan et al (2002) and Gonzalez (2008). Other definitions can also be found in Ovia (2005) and Oginni et al (2013) where internet banking is referred to as the provision of banking services to customers through internet technology or as the use of intelligent devices through the internet to effect banking operation (most especially the provision of retail and small value banking products and services).

According to Mols et al (1999) the acceptance and continued use of internet services otherwise referred to as internet diffusion or adoption in banking; is more determined by customers' acceptance than by the sellers' (bank) offerings. O' Connell (1996) also demonstrated that the explanation for slow growth in internet adoption is more dependent on security issues and lack of knowledge about the availability of such service. On these bases Wallis (1997) opined that internet adoption as a new technology by customer depends mainly on awareness, ease of use, safety and security, cost of usage, level of technical skill and availability of computer facilities and access to the internet.

Among the many academic attempts undertaken to identify and classify factors influencing technology innovation adoption include those by Rogers (1983) and Kim Gallier 2004) who adopted stratification under selected characteristics. Tornatzty and Fleischer (1990) identified different innovation influencing factors which are categorized under organizational technological and environmental determinants while Kimberly and Evarisko (1981) identified three groups of predictors of innovation; namely characteristics of leaders, organization and environment. In many of these previous attempts the influence of environmental factors comprising pressures from customers 
competitors, supplier; role of government; partners alliances have been given considerable significance in determining technological infrastructural availability; image of internet technology and user expectations; Aguila-Obra and Padilla-Metendez 2006 and Gholami and Ogun 2009. In summary influential factors can be categorized under managerial, organizational technological and environmental factors.

Several theories have also been postulated by researchers to explain the basis for consumers' intention to adopt internet banking. Two of the models often cited by previous researches as been most relevant in explaining technology adoption are Rogers (1983) Diffusion of Innovation (DOI) and Davis (1989) Technology Acceptance Model Technology (TAM) both of which indentified specific attributes or determining success factors influencing internet adoption. However the one that is most relevant to the present study is TAM which was originally propounded by Davis, (1989) and expanded by Rogers (1995) who proposed five basic characteristics of innovation to explain technology adoption rate; namely Relative Advantage, Compatibility, Complexity, Triability and Observability.

TAM according to Ayo (2008) is an information system theory model of how users come to accept and use a technology while Abdul Kabeer (2013) adapted four theoretical constructs namely Perceived Usefulness (PU), Perceived Ease of Use (PEOU), Perceived Credibility (PCRED) and Convenience (CONV) as significant parameters to explain adoption of internet banking among students of higher institutions in Pakistan. Academic studies on factors influencing successful adoption of internet for payments either through mobile or e-payments system abound. These factors according to Shon and Swatman (1997) cited in Gholami \& Ogun (2009) are in line with Davis (1989) and Rogers (1995); but paramount among these is the Perceived Ease of Use (PEOU) which according to Tomatzky \& Klein (1983) and O'Callaghan (1992) refers to the expected benefits an individual hopes to receive from adopting a technology. PEOU according to Gholami \& Ogun (2009) include cost reduction, availability and safety among others, while Kyara Bukar 2008 also include convenience in e-payments through availability of network.

More than the two previously emphasized attributes i.e. PEOU and Convenience, in matter relating to financial transactions, issues of Trust and Security also influence the credibility consideration in decisions that relates to adoption of internet banking for payment services. The attributes of credibility according to Havinga et al (1996) and Mahoney et al (2002) is of greater concern as customers also rely on the ability of the bank making available the avenue to ensure that transfer of data or information can be actuated free from the activities of hackers. Other academic works have also adopted similar parameters and in many instances augment the existing model by examining additional factors such as Acceptability, Perceived Benefits, Accessibility, Social Influence, Perceived Risk, Quality of Internal (Website) Connection, Users Technical Skill, Resistance to Change, Mobile Service Quality, Reliability of internet usage among others factors determining user's adoption of internet for banking transactions. These factors are summarized in Figure 1.0 below:

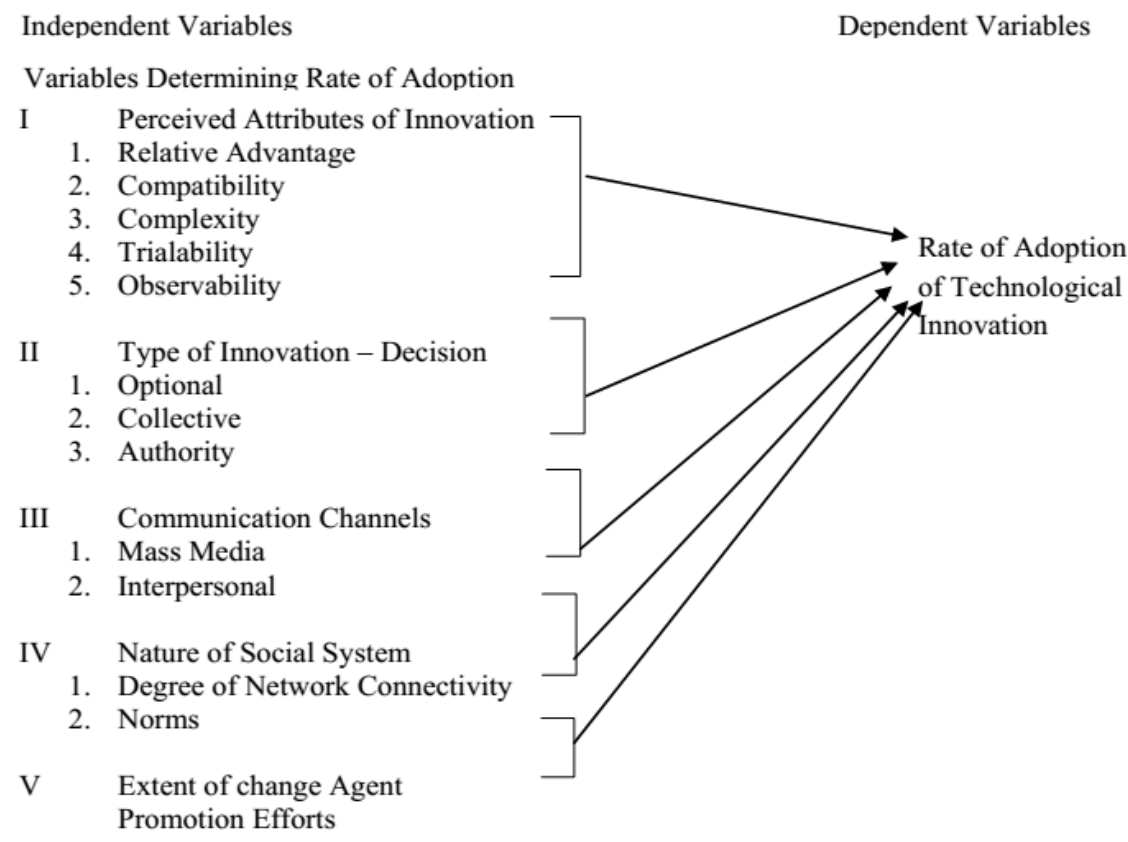


Fig1.0. Variables Determining Rate of Adoption of Technology Innovation (Rogers, 1995)

\section{Methodology}

The research design adopted in the study involved both survey and secondary strategy, given the exploratory and descriptive nature of the research involved. The approach becomes imperative as a means for enabling collection of required data from the target population in an economical way. Data collection is therefore both primary and secondary.

The study focused on University Students Perceived adoption of Internet as a means of access to bank services was motivated by dearth of academic work in this area and the common complaint of mobile connectivity as a major challenge. The populations of the study consist of all students in the five (5) Universities located in Oyo state as of August 2014, namely University of Ibadan (Federal) Ladoke Akintola University of Technology Ogbomoso (State) CETEP City University Ibadan (Private) Lead City University Ibadan (Private) and Ajayi Crowder University Oyo (Private).

Convenience sampling method which is a non-probability sampling involving drawing a sample from part of population nearest to the researcher is adopted in selecting six hundred (600) University Student-bank customers for the administration of a structured questionnaire. Out of this number only five hundred and fifty (550) were duly completed and returned in a useable form. A self-administered questionnaire that consist of two sections; demographic information such as gender, level and programme of study and (B) which relates respondents' opinion on the relationship between selected independent variables such as Perceived Ease Use (PEOU), Perceived Credibility Attributes (PCA); and Convenience (CONV) with the dependent variable being Perceived Usefulness (PU) The study variables were measured using a multi-item five point likert Scale ranging from strongly disagreed (I) to strongly Agreed (5) to denote level of respondent opinion on each of the questionnaire items most of which were adapted from Goodhue and Thompson (1995), Venkatesh and Morris (2000), Wang et al (2003) and Cunningham et al (2005). Independent variables of the study include Quality of bank website, bank technology investment student bank customer loyalty to a bank brand, technology skill acquisition, bank service delivery, security, trust and technophobia. The apriori expectation of the study is that independent variables will influence the dependent variables i.e. intention to adopt internet banking among university students in the study area.

Based on the conceptual variables identified and the research hypothesis presented in section one above, the model below represent the relationship of the constructs identified in the literature.

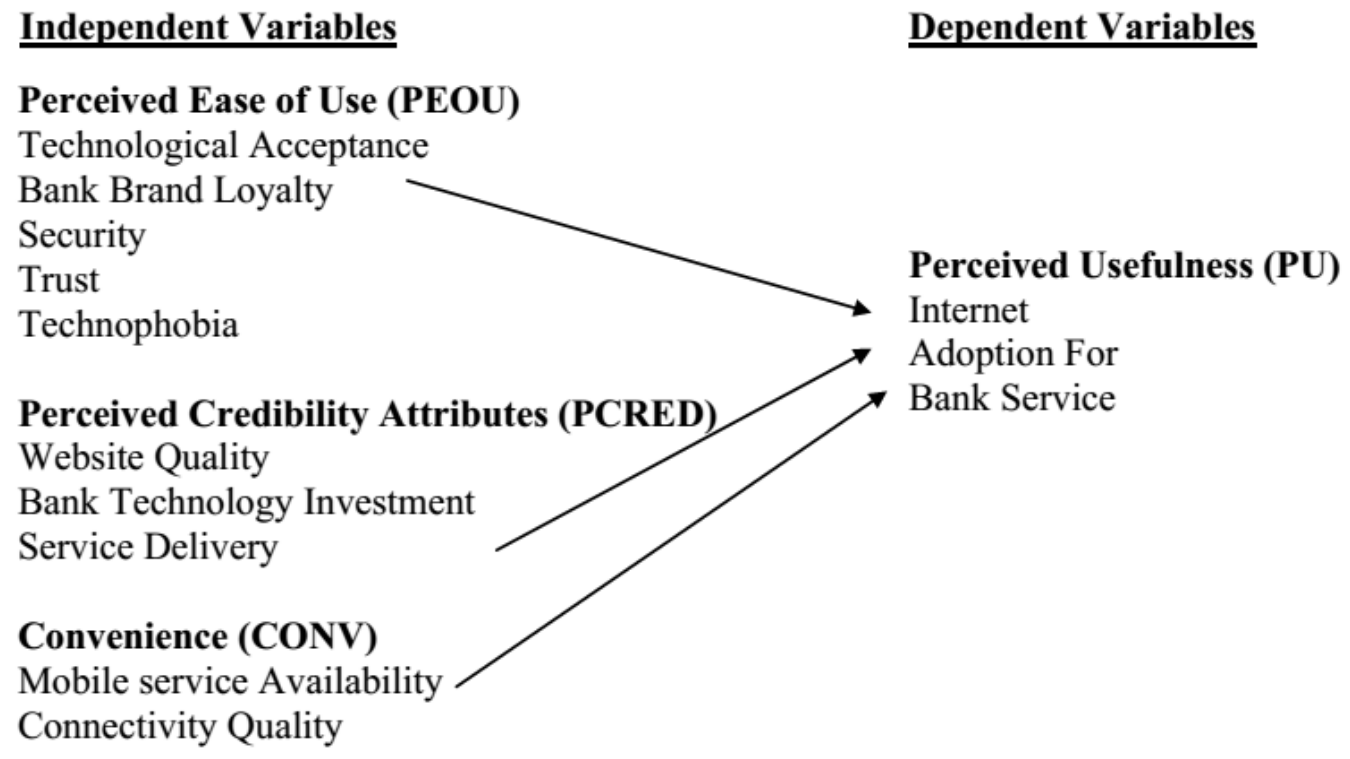

Fig2.0. Research Model - An Adaptation of Rogers Model (1995)

The model posit that internet adoption by university student bank customers in the study area i.e. Oyo State Nigeria will be influenced by adoption attributes presented as independent variables in the above model and equation 2.1 below: 
Onaolapo A. R. \& Anene E. C.

$\mathrm{PU}=\mathrm{f}(\mathrm{PEOU}+\mathrm{PCRED}+\mathrm{CONV}+\mathrm{e})$

Where the terms are as described in the model above.

Collected data were analyzed using both the Pearson Product Moment Correlation and the Multiple Linear Regression Analysis using STATA 11 to ascertain whether the independent variables explain the variance in the dependent variable (i.e. behavioural intention to adopt internet banking services) at a significant level.

\section{RESUlT AND DISCUSSION}

Demographic profile of students for the study includes gender, age group, school type and program of study. Table 4.1 presents the demographic characteristics of the sampled students. Gender distribution is dominated by Male $58 \%$ to female $42 \%$ while majority of the respondent are of the age bracket $25 y e a r s$ and below. The breakdown of school type indicate majority are from State Universities $55.5 \%$ while Engineering and Technology provided the bulk of the student respondents in term of programme of study.

Table4.1. Demographic Characteristics of the Respondents

\begin{tabular}{|l|l|l|l|}
\hline Variable & Classification & Frequency & Percentage \\
\hline \multirow{5}{*}{ Gender } & Male & 319 & 58.0 \\
\cline { 2 - 4 } & Female & 231 & 42.0 \\
\cline { 2 - 4 } & & 550 & $\mathbf{1 0 0 . 0}$ \\
\hline \multirow{5}{*}{ Age Group } & Up to 18 & 187 & 34.0 \\
\cline { 2 - 4 } & 19 t 25 & 220 & 40.0 \\
\cline { 2 - 4 } & More than 25 & 143 & 26.0 \\
\cline { 2 - 4 } & & & $\mathbf{1 0 0 . 0}$ \\
\hline Program of study & Federal & 125 & 22.7 \\
\cline { 2 - 4 } & State & 305 & 55.5 \\
\cline { 2 - 4 } & Private & 120 & 21.8 \\
\cline { 2 - 4 } & & 150 & $\mathbf{1 0 0 . 0}$ \\
\cline { 2 - 4 } & Science & 27.3 \\
\cline { 2 - 4 } & Engineering and Technology & 320 & 58.2 \\
\cline { 2 - 4 } & Arts and Humanities & 80 & 14.5 \\
\cline { 2 - 4 } & & $\mathbf{1 0 0 . 0}$ \\
\hline
\end{tabular}

Source: Field Survey

Summaries of study variables are presented in Table 4.2 below. Twelve (12) variables namely bank website quality (wsq) Quality of Mobile Connectivity (qmc) Loyalty to Bank brand (lbb) Technical skill acquisition (tsa) mobile service quality (msq) Bank service Delivery (bsd) service quality (sq) Security, Trust, loyalty and Technophobia are the independent variables. The major dependent variable is Adoption of internet banking (aib). Opinion ratings range from 1to5.

Table4.2. Descriptive Analysis of Study Variables

\begin{tabular}{|l|l|l|l|l|l|}
\hline Variable & Obs & Mean & Std. Dev. & Min & Max \\
\hline Wsq & 550 & 2.127273 & 1.342245 & 1 & 5 \\
\hline Aib & 550 & 2.203636 & 1.349082 & 1 & 5 \\
\hline Qmc & 550 & 2.896364 & 1.603214 & 1 & 5 \\
\hline Lbb & 550 & 2.232727 & 1.393591 & 1 & 5 \\
\hline Tsa & 550 & 2.236364 & 1.365242 & 1 & 5 \\
\hline Msq & 550 & 2.169091 & 1.354527 & 1 & 5 \\
\hline Bsd & 550 & 2.209091 & 1.367696 & 1 & 5 \\
\hline Sq & 550 & 2.305455 & 1.371505 & 1 & 5 \\
\hline Security & 550 & 2.378182 & 1.431711 & 1 & 5 \\
\hline Trust & 550 & 2.347273 & 1.275145 & 1 & 5 \\
\hline Loyalty & 550 & 2.463636 & 1.318754 & 1 & 5 \\
\hline Technophobia & 550 & 2.6 & 1.441008 & 1 & 5 \\
\hline Source: Data & & & & \\
\hline
\end{tabular}

Source: Data generated from Analysis of variables using stat all

Four hypotheses designed to evaluate respondents' opinion relate to Perceived Ease of Use, Credibility Attributes i.e. customer opinions on security attribute and Convenience as determinants for adoption of internet banking by the respondents. A Likert scale measure of respondents' opinion was also employed to analyze variables involved in hypotheses one (1) to three (3) as well as relationship 
between sampled banks financial information on equity, capitalization, investment in ICT and Profitability using both Regression and Correlation Analysis. Findings based on the analysis are presented below in sections 4.1- 4.4.

\subsection{Perceived Ease of Use [Hypothesis $1\left(\mathrm{H}_{01}\right)$ ]}

Hypothesis one is a test of relationship between adoption of Internet Banking (aib) and Usage attributes as a means of evaluating customers' Perceived Ease of Use. Seven (7) technology usage attributes namely website quality (wsq) quality of mobile connectivity (qmc) mobile service quality (msq) Loyalty to bank brand (lbb) Technical Skill acquisition (tsa) bank service quality (bsq) and bank service quality are related. Findings based on a regression result was $\mathrm{R}^{2}=95.68 \%(0.9568)$; an indication of high predictive power of the independent variables to determine the extent of variation in the adoption of internet banking. Out of the seven explanatory variables adopted to determine the extent to which variation in dependent variable (aib) can be explained only (2) two are significant at $5 \%$ (0.05), namely Service Quality (sq) (p-and t-values at (0.00)12.5) and Trust (0.00)5.89 with technophobia being marginally significant at $10 \%$ given $p$-and t-value of $(0.097) 1.66$. Both Cameron and Trivedi decomposition of IM-Test and marginal effects after regression gave $\mathrm{Y}=2.206$, an indication that the values of independent variables are well fitted and can be used to predict the dependent variable i.e. adoption of internet banking (aib).

A pair wise correlation analysis conducted to determine the power of the seven (7) explanatory variables in predicting changes in the dependent variables found four (4) of the variables (i.e. Service Quality (sq) Trust, Loyalty and Technophobia) to be significant at 5\% level of significance; thus buttressing the regression results presented in Table 4.3.

Pooled OLS Regression Analysis of Relationship between Adoption of Internet Banking and Attributes of Perceived Usage

\begin{tabular}{|l|l|l|l|l|ll|}
\hline aib & Coef. & Std. Err. & $\mathbf{T}$ & $\mathbf{P}>\mid \mathbf{t}$ & \multicolumn{2}{|l|}{ [95\% Conf. Interval] } \\
\hline sq. & 6964995 & .0555312 & $\mathbf{1 2 . 5 4}$ & $\mathbf{0 . 0 0 0}$ & .5874177 & .80558 \\
\hline security & .0146172 & .0540931 & 0.27 & $0.787 q$ & -.0916398 & .1208742 \\
\hline trust & .2601892 & .0441953 & $\mathbf{5 . 8 9}$ & $\mathbf{0 . 0 0 0}$ & .3470036 & .1733748 \\
\hline loyalty & -.0590645 & .0516139 & -1.14 & 0.253 & .042322 & -.1604515 \\
\hline technophobia & .0702843 & .0422641 & $\mathbf{1 . 6 6}$ & $\mathbf{0 . 0 9 7}$ & .153305 & -.0127366 \\
\hline cons & -.0848348 & .0262417 & -3.23 & 0.001 & -.0332873 & -.1363822 \\
\hline
\end{tabular}

Number of obs $=550 ; F(5,544)=2407.07 ;$ Prob $>F=0.0000 ; R^{2}=0.9568$ Adj $R^{2}=0.9564 ;$ Root MSE = .28184

.estat imtest Cameron \& Trivedi's decomposition of IM-test $Y=2.206$,

Table4.4. Pair-wise Correlation between Internet Adoption and Perceived Ease of Use Attributes

\begin{tabular}{|c|c|c|c|c|c|c|}
\hline $\mathrm{Aib} \longrightarrow$ & $\mathrm{sq} \longrightarrow$ & security $\longrightarrow$ & $\longrightarrow$ & loyalty $\longrightarrow$ & techno a & $\longrightarrow$ \\
\hline Aib & 1.0000 & & & & & \\
\hline $\mathrm{Sq}$ & 0.9754* & 1.0000 & & & & \\
\hline Security & 0.9644* & $0.9837 *$ & 1.0000 & & & \\
\hline Trust & $0.9562 *$ & $0.9599 *$ & $0.9566^{*}$ & 1.0000 & & \\
\hline Loyalty & 0.9461* & $0.9568 *$ & $0.9498 *$ & $0.9699 *$ & 1.0000 & \\
\hline techno a & $0.9405 *$ & $0.9486^{*}$ & $0.9581 *$ & $0.9560^{*}$ & $0.9729 *$ & 1.0000 \\
\hline
\end{tabular}

*0.05 level of significance

\subsection{Perceived Credibility Attributes Hypothesis $2\left(\mathrm{H}_{02}\right)$}

In order to test the influence of credibility attributes on mobile service connectivity as attributes of usefulness such as technical skill acquisition (tsa); Service quality (sq), Security and loyalty to bank brand (lbb) are regressed against respondents' opinion of perceived of credibility using quality of mobile connectivity (qmc) as surrogate. The overall predictive power of a tested regression model indicated $\mathrm{R}^{2}=0.954$, Adjusted $\mathrm{R}^{2}=0.953$ with $\mathrm{P}>\mathrm{F}$ value $=0.000$; implying a highly significant nature of the predictive power of the explanatory (credibility) variables as determinants of customers' perception of the quality of a bank website quality. Apart from the significant predictive power of the independent variables an examination of each of the explanatory variables indicate that only two 
them; namely loyalty to bank brand (lbb) with $t$ and $p$ values of $7.73(0.000)$ and Technical Skill Acquisition (tsa) 4.06(0.000) have significant predictive influence on website quality.

As in hypothesis one (1) above; both the Cameron \& Trivedi decomposition of IM-Test and Marginal effects after regression indicate $\mathrm{p}=0.000$ with $\mathrm{Y}=2.127$ an indication that the model $\mathrm{s}$ well fitted to predict variance in the dependent variable. Results of the regression analysis of the relationship between website quality and Credibility Attributes (C. A.) high degree of association between website quality and these attributes as presented in table 4.5.

Table4.5. OLS Regression Result between Bank Website Quality and Credibility Attributes

\begin{tabular}{|l|l|l|l|l|ll|}
\hline Wsq & Coef. & Std. Err. & $\mathbf{t}$ & $\mathbf{P}>|\mathbf{t}|$ & [95\% Conf. Interval] \\
\hline lbb & .5449201 & .0704998 & $\mathbf{7 . 7 3}$ & $\mathbf{0 . 0 0 0}$ & .4064354 & .6834048 \\
\hline tsa & .3328634 & .0819706 & $\mathbf{4 . 0 6}$ & $\mathbf{0 . 0 0 0}$ & .1718463 & .4938805 \\
\hline sq & -.0030688 & .0663624 & -0.05 & 0.963 & -.1334263 & .1272887 \\
\hline security & .0745039 & .0494082 & 1.51 & 0.132 & -.02255 & .1715577 \\
\hline _cons & -.0038977 & .0242397 & -0.16 & 0.872 & -.0515124 & .0437171 \\
\hline
\end{tabular}

$R$-squared $=0.9542 ;$ Adj $R$-squared $=0.9539 ;$ Prob $>F=0.0000 ; F(4,545)=2840.12$

Number of obs $=550$ Root MSE $=0.28823$.estat imtest: Cameron \& Trivedi's decomposition of IM-test (Marginal effects after regress) $Y=$ Fitted values $($ predict $)=2.1272727$

\subsection{Perceived Convenience Attributes Hypothesis $3\left(\mathbf{H}_{03}\right)$}

In order to test the influence of convenience attributes on Mobile Service Connectivity attributes such as technical skill acquisitions (tsa), service quality (sq), level of technophobia and loyalty to bank brand are regressed against respondents' opinions of perceived quality of mobile connectivity (qmc). Overall predictive power of the model as presented below in table 4.6 indicate $\mathrm{R}^{2}=0.884$; Adjusted $\mathrm{R}^{2}=0.883$; with $\mathrm{p}$-value 0.0000 . Two of the explanatory variables (out of four) namely technophobia $\mathrm{t}=15.79, \mathrm{p}=0.0000$ and Service Quality (sq) with $\mathrm{t}=3.12, \mathrm{p}=0.0002$ have significant predictive influence on the variation in the dependent variable i.e. Quality of Mobile Connectivity (i.e. Perceived Convenience) as attributes determining adoption of internet banking by students customers, based on quality of mobile connectivity.

In line with the result obtained in Hypothesis One above, both the Cameron and Trivedi decomposition test of Marginal Effect undertaken to determine the extent of fitness between the four explanatory variables and dependent variable $(\mathrm{Y})$ i.e. mobile connectivity indicate $\mathrm{Y}=$ fitted value Prediction $=2.8963636$. Furthermore, a pair-wise correlation analysis conducted to determine the predictive influence of the four independent variables i.e. loyalty to bank brand (lbb), technical skill, technophobia and service quality as surrogate convenience variables, attested to the significance influence of the variables as the four (4) selected convenience attributes are significantly correlated to qme at 5\% level of significance (the dependent variable) according to table 4.7 presented below.

Table4.6. OLS Regression Results of Relationship between Service Connectivity and Convenience Attributes

\begin{tabular}{|l|l|l|l|l|l|}
\hline Qmc & Coef. & Std. Err. & $\mathbf{t}$ & $\mathbf{P}>|\mathbf{t}|$ & {$[\mathbf{9 5 \%}$ Conf. Interval] } \\
\hline Lbb & -.1366984 & .1320617 & -1.04 & 0.301 & -.3961106 \\
\hline technophobia & .8334323 & .0527862 & $\mathbf{1 5 . 7 9}$ & $\mathbf{0 . 0 0 0}$ & .729743 \\
\hline Tsa & .0618054 & .1545028 & 0.40 & 0.689 & -.2416886 \\
\hline Sq & .3091977 & .0990418 & $\mathbf{3 . 1 2}$ & $\mathbf{0 . 0 0 2}$ & .1146473 \\
\hline Cons & .1835893 & .0490948 & 3.74 & 0.000 & .0871511 \\
\hline
\end{tabular}

- Adj $R^{2}=0.8832 ; R^{2}=0.8840 ;$ Prob $>F=0.0000 ; F(4,545)=1038.38$

Estat imtest: Cameron \& Trivedi's decomposition of IM-test; Marginal effects after regression with Y=Fitted values $($ predict $)=2.8963636$.

Table4.8. Pair-wise Correlations between Quality of Mobile Connectivity and Convenience Variables

\begin{tabular}{|l|l|l|l|l|l|}
\hline Variables & qmc & Lbb & techno a & tsa & sq \\
\hline Qmc & 1.0000 & & & & \\
\hline Lbb & $\mathbf{0 . 8 9 7 8 *}$ & 1.0000 & & & \\
\hline
\end{tabular}


Bank Service Quality, Mobile Connectivity and Adoption of Internet Banking Among Selected University Students in Oyo State Nigeria

\begin{tabular}{|l|l|l|l|l|l|}
\hline Technophobia & $\mathbf{0 . 9 3 7 6}^{*}$ & $0.9426^{*}$ & 1.0000 & & \\
\hline Tsa & $\mathbf{0 . 9 0 0 8}^{*}$ & $0.9916^{*}$ & $0.9425^{*}$ & 1.0000 & \\
\hline Sq & $\mathbf{0 . 9 1 0 7}^{*}$ & $0.9767^{*}$ & $0.9486^{*}$ & $0.9828^{*}$ & 1.0000 \\
\hline
\end{tabular}

*0.05 level of significance

\subsection{Relationship between selected Nigerian Bank Technology Investment and Financial Performance. [Hypothesis $4\left(\mathrm{H}_{04}\right)$ ]}

An attempt to evaluate the effectiveness of bank technology investment on financial performance was undertaken in table 4.8 below using both multiple regression and correlation analysis. Five bank specific performance variables namely equity, total capitalization, deposit; and profit and investment in ICT for selected banks were analysed for relationship. A multiple regression of the variables using equity as in dependent variable and four explanatory variables imply that changes owners equity are predictably based on profit, deposit. ICT investment and total capitalization as independent variables. In particular three of the explanatory variables i.e. I.C.T. investment; level of Capitalization and deposit are significantly related to equity at $5 \%$ level of significance. A pair wise correlation analysis undertaken further buttressed the significance of these variables with regard to the level of total-asset especially with respect to equity and I.C.T. investment. On the basis of the findings the study reject the null hypothesis that state no significance relationship exist between technology acquisition and bank financial performance.

Table4.8. OLS Regression Analysis of Relationship between Bank Specific Variables ICT Investment

\begin{tabular}{|l|l|l|l|l|ll|}
\hline Asset & Coef. & Std. Err. & t & P>|t| & \multicolumn{2}{|c|}{$[\mathbf{9 5 \%}$ Conf. Interval] } \\
\hline equity & .2154483 & .4060393 & 0.53 & 0.599 & -.6106448 & 1.041541 \\
\hline ICT & .2630291 & .1082939 & $\mathbf{2 . 4 3}$ & $\mathbf{0 . 0 2 1}$ & .0427035 & .4833548 \\
\hline Total capitalization & 1.445618 & .7344971 & $\mathbf{1 . 9 7}$ & $\mathbf{0 . 0 5 7}$ & -.0487281 & 2.939963 \\
\hline deposit| & 1.060041 & .1128145 & $\mathbf{9 . 4 0}$ & $\mathbf{0 . 0 0 0}$ & .8305182 & 1.289564 \\
\hline profit| & -.0016204 & .1021899 & $*_{-} 0.02$ & 0.987 & -.2095274 & .2062866 \\
\hline cons & 26692.01 & 20396.96 & 1.31 & 0.200 & -14805.93 & 68189.94 \\
\hline
\end{tabular}

$F(5,33)=128.24$, Prob $>F=0.0000, R$-squared $=0.9511$, Adj $R$-squared $=0.9436$

Table4.10. A Pair-wise-Correlation Analysis between Bank Asset, Equity Capitalization I.T. Investments and Deposits.

\begin{tabular}{|l|l|l|l|l|l|}
\hline & Asset & Equity I.C.T. & Total capitalization & capitalization & Deposit \\
\hline Asset & 1.0000 & & & & \\
\hline Equity & $0.8603^{*}$ & 1.0000 & & & \\
\hline I.C.T. & $0.7635^{*}$ & $0.8132^{*}$ & 1.0000 & & \\
\hline Capitalization & $0.6771^{*}$ & $0.5069^{*}$ & $0.5391^{*}$ & 1.0000 & \\
\hline Deposit & $0.9596^{*}$ & $0.8400^{*}$ & $0.6752^{*}$ & $0.6206^{*}$ & 1.0000 \\
\hline
\end{tabular}

0.05 level of significance

\section{SUMMARY AND CONCLUSIONS}

The study evaluated the relationship between bank service quality, Mobile connectivity and adoption of internet banking among selected University Students in Oyo State, Nigeria. Specific objectives of the study include an examination of the relationship between bank service quality, availability of mobile connectivity and adoption of internet banking among sampled university students in Oyo state, Nigeria. A supply side analysis of the relationship between technology investment and bank financial performance was also undertaken. Four hypothesis postulated in their null form are tested for significance using both regression and correlation analyses. Findings from the study based on a regression result $\left(\mathrm{R}^{2}=95.68 \%\right)$ indicate a high predictive power of such independent variables as Service Quality, Trust and Technophobia as significant variables determining Perceived Ease of adoption of internet banking while similar attributes also have significant predictive influence on website quality. These findings are in line with Goodhue and Thompson (1995), Venkatesh and Morris (2000), Wang et al (2003) and Cunningham et al (2005) where these attributes are adopted with significant results. The study also found explanatory power of such variables as technical skill acquisition (tsa); Security loyalty to bank brand (lbb) and technophobia (i.e. fear of not fully 
understanding technology involved) as significant predictive influence determining credibility and adoption of internet banking by bank students customers in the study area. There exists a convergence between these findings that attributes of perceived usage as significant indices of credibility in Technology adoption and similar academic work by Havinga et al (1996) and Mahoney et al (2002).

Based on these findings the study concludes that relationship exists between bank service quality, mobile connectivity and internet banking adoption among selected Nigerian University students in Oyo-state, Nigeria. The study also conclude that high predictive influences exist between bank services quality, availability of mobile connectivity and adoption of internet banking among sampled university students in the study area.

\section{RECOMMENDATIONS}

On the basis of the findings the study recommends among others the needs for Nigerian banks to provide some levels of users education in terms of procedures involved in the adoption of internet for accessing bank services. Given the correlation between bank technology investments, deposits and earnings, there is the needs for Nigerian banks to enter into some partnership arrangement with service providers with a view to managing costs and quality of mobile connectivity into their website. The existence of a high level of relationship between attributes of service quality, security, trust and mobile connectivity emphasized the necessity for pulling in place an enduring and workable policies by the government and its agencies with a view to improve the quality of mobile services available in many Nigerian cities.

\section{REFERENCES}

AbdulKabeer K. (2013) An empirical study of factors influencing adoption of internet banking among students of higher education: Evidence from Pakistan. Online at http://mpra.ub.unimuenchen.de/48611 MPRA Paper No 48611.

Aguila-Obra, A. R. D., \& Padilla-Melendez, A. (2006) Organizational factors affecting Internet technology Adoption Internet Research, 16(1), 94-110.

Auta M. E. (2010) E-banking in Developing Economy. Empirical Evidence from Nigeria. Journal of Applied Quantitative Methods 5(2).

Ayo C. K; Adesina A. and Uyinomen O. E. (2008) An empirical investigation of the level of User's Acceptance of E-banking in Nigeria: Based on Technology Acceptance Model, Proceeding of First International Conference on Mobile Computing, Wireless Communication, E-health, Mhealth and Telemedicine (MWEMTeM 2008) ISBN: 978-2902-43-8.

Chiemeke S. C., Evwiekpaefe A. E. and Chefe F. O. (2006) The Adoption of Internet Banking in Nigeria: An Empirical investigation. Journal of Internet Banking and Commerce, December 2006 Vol. II No. 3

Cunningham L. F. Gerlach J. and Harper M.D. (2005) Perceived risk and e-banking services: An Analysis from the perspective of the customer. Journal of financial Services Marketing, 10(2): 165-178.

Davis F. D. (1989) Perceived Usefulness, Perceived Ease of Use and User Acceptance of Information Technology MIS Quarterly, 13(3), 319-340

Egland K. L., Furst K., Nolle D. E. and Robertson D., (1998) Banking Over the Internet. Quarterly Journal of Office of Comptroller of Currency 17(4).

Efina (2014) Access to Financial Services in Nigeria 2014 Survey 2, Dec. 2014.

Furst K. Lang W. Nolle D. E. (2000) Who Offers Internet Banking? Quarterly Journal Office of the Comptroller of the currency 19(2): 27-46

Gholami R. and Ogun A. (2009) Factors Affecting e-payment: Adoption in Nigeria Operations and Information Management Group, Aston Business School Aston Triangle, Birmingham B47ET, UK.

Gonzalez M. E. (2008) An Alternative Approach in Service Quality: An E-banking Case Study. Quarterly Manager 15:41-48

Goodhue D. L. and Thompson R. L. (1995) Task Technology Fit and Individual Performance, MIS Quarterly, 19(2) 213-236. 
Bank Service Quality, Mobile Connectivity and Adoption of Internet Banking Among Selected University Students in Oyo State Nigeria

Havinga P., Smit, G.J.M., \& Helme A. (1996) Survey of Electronic Payment, methods and systems, University of Twente, Department of Computer science.

IIC Africa (2013) Study on International Internet Connectivity in Sub-saharan Africa. Report Presented during Seminar and Meeting of the Regional Group of ITU study Group 3 for Africa in March 2013.

Kimberly, J. R. \& Evanisko, M. J. (1981) Organization Innovation: the influence of individual, Organizational and contextual factors on hospital adoption of technology and administrative innovation. Academy of management Journal, 24(4) 689-713.

Kim C. \& Gallier, R. D. (2004) Towards a diffusion model for internet systems. Internet Research 14(2), 155-166.

Kirk T. (2009) CARTA 8 Carribean Group of Banking Supervisors; IT workshop for Regional Bank Examiners June 23-25, 2009 Georgetown Guyana.

Kyari B. Business Day Online http://businessdayonline.com/entrepreneurtoday/ 13969.htm/

Mohammed, A. O. \& Saad, A. A. (2011). The Impact of E-banking on The performance of Jordanian Banks. Journal of Internet Banking and Commerce August 2011, vol. 16.

Mols, N. P., Bukh, P., \& Nielsen, J. (1999) Distribution channels strategies in Danish retail Banking. International Journal of Banking Marketing, 27(1), 37-47.

O’Connel, B. (1996) Australian Banking On the Internet Fact or Fiction? The Australian Banker, 12:212-214.

Oginni, S. O. Mohammed A. El-maude J. G. (2013) E-banking and banking performance: Evidence from Nigeria.

Ovia J. (2001) Internet Banking Practices and Potentials in Nigeria; A Paper Presented at the Conference Organized by the Institute of Chartered Accountant of Nigeria ICAN Lagos September 52001.

Pyuan C. S; Scruggs L. and Nam N. (2002) Internet Banking in the United States, Japan and Europe. Multinational Business Review Pp 73:81.

Raji T. I. and Adeyemo Z. K. (2008) Performance of qpsk and 4qam signaling in mobile Communication Channel Using Generalized Selection Combiner Proceedings of the First International Conference On Mobile Computing, Wireless Communication, E-health, M-health \& Telemedicine MWEMTeM' 08 held at senate Chamber Ladoke Akintola University of Technology (LAUTECH) Ogbomoso, Nigeria Nov. $18^{\text {th }}-20^{\text {th }} 2008$.

Roggers, E. M., (1983). Diffusion of Innovations ( $3^{\text {rd }}$ Ed) New York: Free Press

Rogers E. (1995) Diffusion of Innovations, Free Press New York

Shekhar K. C. and Shekhar L. (2013) Banking Theory and Practice Incorporating Banking Law and Foreign Exchange $20^{\text {th }}$ Edition Vikas Publishing House PVTLtd ISBN 978-81-259-3715-9.

Tornatzky L.G. \& Fleischer, M. (1990) The process of Technology Innovation Lexington, MA: Lexington Books.

Venkatesh, V. and Morris M. (2003) User Acceptance of Information Technology: Towards a Unified view. Management Information System Quarterly, 27 (1), 18.

Wallis Report (1997), The Financial System Inquiry Final Report (Chairman: Mr. Stan Wallis); AGPS, Canberva Australia.

Wang Y. S; Wang Y. M; Lin H. H. and Tang T. I (2004) "Determinants of user Acceptance of Internet banking: An empirical study". International Journal of Service Industry Management Vol.9 No. 12004 Pp 49-56. 